\title{
Thrombotic thrombocytopenic purpura and haemolytic uraemic syndrome in three siblings
}

\author{
M ELIAS, ${ }^{*}$ J HOROWITZ,$\dagger$ I TAL,$\dagger$ D KOHN,,$*$ AND E FLATAU* \\ Departments of *Internal Medicine B and †Pediatrics A, Central Emek Hospital, Afula, Israel
}

SUMmaRy Two brothers and one sister had three variants of thrombotic thrombocytopenic purpura and haemolytic uraemic syndrome (the 'TTP-HUS' complex). The sister had a chronic fatal variant of thrombotic thrombocytopenic purpura with severe neurological manifestation. One brother had a chronic relapsing disease but the kidneys were not affected, and the other brother had haemolytic uraemic syndrome. This occurrence in one family supports the hypothesis that haemolytic uraemic syndrome and thrombotic thrombocytopenic purpura are acutally two variants of the same disease.

Thrombotic thrombocytopenic purpura and haemolytic uraemic syndrome are two closely related syndromes, in which thrombocytopenia, microangiopathic haemolytic anaemia, fever, and renal impairment are common features. 'Many authors suggest that these two syndromes actually represent a range of illness with the same basic disease process. ${ }^{2}$ Fluctuating neurologic signs are more often observed in thrombotic thrombocytopenic purpura; haemolytic uraemic syndrome is a process mainly affecting the kidneys. Haemolytic uraemic syndrome usually affects children younger than 8 years of age, while thrombotic thrombocytopenic purpura is rare in childhood. ${ }^{12}$ The cases described below occurred 17 years apart in three siblings, each sibling manifesting a different variant of the 'TTPHUS' complex.

\section{Case reports}

Case 1. A 1 year old girl, daughter of healthy unrelated Arab parents, with seven healthy sisters and two brothers was admitted in December 1967 with diarrhoea, vomiting, and severe anaemia. On admission she was lethargic, pale, and tachycardic. The blood count showed anaemia, thrombocytopenia, and evidence of microangiopathic haemolysis (table). Coombs' test was negative and the serum

Table Clinical and laboratory data of the three patients

\begin{tabular}{|c|c|c|c|c|}
\hline & $\begin{array}{l}\text { Case } 1 \\
\text { Episodes of disease } \\
\text { December } 1967\end{array}$ & February 1968 & July 1968 & $\begin{array}{l}\text { Case } 2 \\
\text { Episodes of disease } \\
\text { December } 1968\end{array}$ \\
\hline Age (years) & 1 & 1 year 2 months & 1 year 7 months & 2 months \\
\hline Presenting symptoms & Vomiting, diarrhoca & Fever, gingival blecding & $\begin{array}{l}\text { Left hemiparesis, left } \\
\text { facial palsy }\end{array}$ & Fever. lethargy \\
\hline Blood pressure $(\mathrm{mm} \mathrm{Hg})$ & & $100 / 60$ & $110 / 60$ & \\
\hline Haemoglobin $\mathrm{g} / \mathrm{l}$ & 43 & 60 & 60 & 35 \\
\hline Reticulocytes $(\%)$ & 21 & $6 \cdot 8$ & 15 & $5 \cdot 6$ \\
\hline Platelets $\times 10^{9} / 1$ & 17 & 65 & 13 & 21 \\
\hline Bilirubin ind/total $(\mu \mathrm{mol} / \mathrm{l})$ & $25 \cdot 7 / 3(0 \cdot 8$ & $59 \cdot 9 / 63 \cdot 3$ & $51 \cdot 3 / 59 \cdot 9$ & \\
\hline \multicolumn{5}{|l|}{ Lactate dehydrogenase U/I } \\
\hline Urea $(\mathrm{mmol} / \mathrm{l})$ & & $22 \cdot 5$ & $12 \cdot 1$ & $8 \cdot 2$ \\
\hline Other & & $\begin{array}{l}\text { Proteinuria, } \\
\text { red cell casts }\end{array}$ & $\begin{array}{l}\text { Proteinuria, } \\
\text { red cell casts }\end{array}$ & \\
\hline Treatment & Blood transfusions & Prednisone, azathioprine & Prednisone & Blood transfusions \\
\hline
\end{tabular}


urea concentration was normal. The patient received blood transfusions and her haemoglobin concentration rose to $92 \mathrm{~g} / \mathrm{l}$. She was discharged after 16 days with the diagnosis of anaemia and throbocytopenia.

The patient was readmitted five weeks later for fever and gingival bleeding. On physical examination she was pale, jaundiced, and ecchymotic with submucosal bleeding. The haemoglobin was $60 \mathrm{~g} / \mathrm{l}$ with reticulocytosis of $6 \cdot 8 \%$, and a platelet count of $65 \times 10^{9} / 1$. Serum urea concentration was $22.5 \mathrm{mmol} / \mathrm{l}$, and bilirubin $63.3 \mu \mathrm{mol} / \mathrm{l}$. Urinalysis showed +3 proteinuria and a few blood cell casts (table).

The peripheral smear showed fragmented red blood cells with burr cells. The diagnosis of thrombotic thrombocytopenic purpura was considered. Blood transfusion was given and the patient received prednisone $1 \mathrm{mg} / \mathrm{kg} /$ day for two weeks without any improvement in her condition. At this stage, despite normal results for immunological laboratory tests (LE cells, Coombs' test, and antinuclear factor were all negative), immunosuppressive treatment with azathioprine $3 \mathrm{mg} / \mathrm{kg} / \mathrm{day}$ was given for four weeks, again without any improvement in her condition. She was readmitted two weeks later with severe anaemia, thrombocytopenia, jaundice, transient left facial nerve palsy, and left hemiparesis. Her blood pressure was 110/60 $\mathrm{mm} \mathrm{Hg}$. The urea concentration was normal but urinalysis showed proteinuria and red cell casts. Treatment with prednisone $40 \mathrm{mg} / \mathrm{day}$ was started with transient improvement. Ten months after the onset of her disease, the patient developed generalised convulsions with deep coma and died. The postmortem examination disclosed multiple thrombi in small arterioles and capillaries, with multiple infarcts in the brain. Similar changes in small vessels were found in the skin, kidneys, pancreas, gingiva, and the myocardium. The diagnosis of thrombotic thrombocytopenic purpura was confirmed.

Case 2. The brother of case 1 was diagnosed at the age of 2 months as suffering from thrombotic thrombocytopenic purpura after developing microangiopathic haemolytic anaemia, severe thrombocytopenia, fever, and mild neurological signs (table). After two months in hospital he achieved complete clinical and laboratory remission. The patient was admitted twice more, at the age of 4 and 13 years, with relapses of his disease which were mild and self limiting. At the age of 15 he was admitted to the department of surgery with right lower abdominal pain and confusion. His blood pressure was $120 / 90 \mathrm{~mm} \mathrm{Hg}$. Acute appendicitis was suspected and he underwent surgery. The appendix was normal. After the operation the patient was lethargic with mild confusion. He developed fever, a bleeding tendency with a large haematoma at the site of the incision, and severe anaemia. The patient was transferred to the medical department. Relevant laboratory findings included anaemia, thrombocytopenia, reticulocytosis, and evidence of a haemolytic process. His plasma haptoglobin concentration was $0 \cdot 3 \mathrm{~g} / \mathrm{l}$ (normal $2 \cdot 0-3 \cdot 0 \mathrm{~g} / \mathrm{l})$. Peripheral blood smear showed anisocytosis, piokilocytosis schistocytes, and burr cells. Serum urea concentration and urinalysis were normal. His prothrombin time was $50 \%$; partial thromboplastin time, fibrinogen, and fibrinogen degradation products were normal. Direct and indirect Coombs' tests were negative. The diagnosis of thrombotic thrombocy-

\begin{tabular}{|c|c|c|c|c|c|c|}
\hline \multirow[b]{2}{*}{ March 1972} & \multirow[b]{2}{*}{1981} & \multirow[b]{2}{*}{1983} & \multicolumn{4}{|l|}{$\begin{array}{l}\text { Case } 3 \\
\text { Episodes of disease }\end{array}$} \\
\hline & & & January 1981 & June 1981 & March 1983 & August 1984 \\
\hline 4 & 13 & 15 & 1 year 6 months & 2 & 3 years 6 months & 5 \\
\hline Jaundice & $\begin{array}{l}\text { Jaudice, } \\
\text { pallor }\end{array}$ & $\begin{array}{l}\text { Abdominal pain, } \\
\text { negative laparotomy, } \\
\text { confusion }\end{array}$ & $\begin{array}{l}\text { Fever, anorexia, } \\
\text { lethargy, } \\
\text { confusion }\end{array}$ & $\begin{array}{l}\text { Fever, } \\
\text { haematuria }\end{array}$ & $\begin{array}{l}\text { Fever, } \\
\text { haematuria }\end{array}$ & $\begin{array}{l}\text { Fever, dark } \\
\text { urine }\end{array}$ \\
\hline $120 / 70$ & & $120 / 90$ & & & & $100 / 60$ \\
\hline \multirow[t]{2}{*}{116} & 105 & 70 & 56 & 86 & 110 & 120 \\
\hline & & 6 & $10 \cdot 6$ & 18 & $4 \cdot 4$ & 2 \\
\hline 86 & & 27 & 17 & 48 & 15 & 14 \\
\hline \multirow[t]{2}{*}{$22 \cdot 2 / 44 \cdot 5$} & $59 \cdot 9 / 66 \cdot 7$ & $29 \cdot 0 / 42 \cdot 8$ & $46 \cdot 1 / 49 \cdot 6$ & & & $107 \cdot 7 / 114 \cdot 6$ \\
\hline & 1090 & 1000 & 2350 & 1100 & & \\
\hline \multirow[t]{3}{*}{$9 \cdot 3$} & $14 \cdot 8$ & $14 \cdot 2$ & $17 \cdot 9$ & $16 \cdot 1$ & $18 \cdot 9$ & $12 \cdot 5$ \\
\hline & & & $\begin{array}{l}\text { Hacmaturia, } \\
\text { red cell casts }\end{array}$ & $\begin{array}{l}\text { Red cell casts, } \\
\text { proteinuria }\end{array}$ & $\begin{array}{l}\text { Red cell casts, } \\
\text { proteinuria }\end{array}$ & \\
\hline & & & Blood transfusion & & $\begin{array}{l}\text { Prednisone, } \\
\text { blood transfusions }\end{array}$ & Plasma \\
\hline
\end{tabular}


topenic purpura was made. Considering the benign nature of his disease in the past, no treatment was started; the last (fourth) episode was short and self limiting. The platelet count, the concentration of lactate dehydrogenase, and the peripheral blood morphology returned to normal within a few days, and the patient was discharged well.

Case 3. The 5 year old brother of cases 1 and 2 was hospitalised at the age of 18 months because of lethargy, anorexia, and jaundice nine days after receiving measles vaccination. Microangiopathic haemolytic anaemia, severe thrombocytopenia, and microscopic haematuria with mild proteinuria was found (table). The diagnosis of haemolytic uraemic syndrome was suspected and he received a blood transfusion. His clinical and laboratory condition improved but his laboratory test results returned to normal only six months later. Three additional episodes of the disease were at ages $2,31 / 2$, and 5 years. The patient was admitted with fever, microangiopathic haemolytic anaemia, thrombocytopenia, macroscopic haematuria, mild azotaemia, and proteinuria of $2 \cdot 5-3 \mathrm{~g} / 24$ hours. Haemolytic uraemic syndrome was diagnosed. Steroids and blood transfusion were given and there was a rapid improvement. Between the episodes of the disease the patient was healthy, with normal full blood count, and normal urinalysis.

\section{Discussion}

Familial occurrence of haemolytic uraemic syndrome is well known. ${ }^{3}$ Less frequent is the occurrence of thrombotic thrombocytopenic purpura in families. There are only five such case reports in the literature. ${ }^{+8}$ Although recently similar pathogenic mechanisms have been suggested for both disorders," there is only one report of the occurrence of haemolytic uraemic syndrome and thrombotic thrombocytopenic purpura in the same family. ${ }^{10}$ The cases described here represent the chronic fatal variant of thrombotic thrombocytopenic purpura with dramatic neurological manifestation (case 1), a chronic relapsing variant with no renal disease and only neurological manifestation (case 2), and haemolytic uraemic syndrome (case 3 ).

Enhanced platelet aggregation plays a major part in the pathogenesis of both thrombotic thrombocytopenic purpura and haemolytic uraemic syndrome. It is possible that some families have predisposition for enhanced platelet aggregation, and that some environmental factor triggers the onset or the relapse of the disease. Such predisposition could result from the deficiency of prostacyclin or any other natural inhibitor of platelet aggregation in the plasma. ${ }^{9}$

The three cases described support the hypothesis that haemolytic uraemic syndrome and thrombotic thrombocytopenic purpura are actually two variants of the same disease with the same pathogenesis. Such a hypothesis would explain the fact that some cases may present a 'border line' picture between thrombotic thrombocytopenic purpura and haemolytic uraemic syndrome, as was the case in our third patient.

The recent recognition of mild forms of thrombotic thrombocytopenic purpura may result in a change in the diagnostic criteria for the disease. Indeed even in the series of Ridolfi and Bell only $74 \%$ of the patients had the classical triad and only $40 \%$ had the entire pentad. ${ }^{1}$ We suggest that the combination of thrombocytopenia and Coombs' negative microangiopathic haemolytic anaemia in patients with a family history of thrombotic thrombocytopenic purpura or haemolytic uraemic syndrome should seriously raise the suspicion of a mild form of thrombotic thrombocytopenic purpura (or haemolytic uraemic syndrome) even in the absence of neurological or renal disease, or both.

\section{References}

1 Ridolfi RL. Bell WR. Thrombotic thrombocytopenia purpura: report of 25 cases and review of the literature. Medicine $1981: 60: 413-28$

2 Umlas J, Kaiser J. Thrombohemolytic thrombocytopenia purpura (TTP): a disease or a syndrome? Am J Med 1970;49:723-8.

"Kaplan BS. Chesney RW. Drummond KN. Hemolytic uremic syndrome in families. $N$ Engl $J$ Med 1975;292:1090-3.

${ }^{+}$Norkin SA. Frecdman HI, Evans GW. Thrombotic thrombocytopenic purpura in siblings. Am J Med 1967:43:294-303.

Paz RA. Elijovich F, Barcat JA, Sanchez-Avalos JC. Fatal simultaneous thrombocytopenic purpura in siblings. $\mathrm{Br}$ Med $\mathrm{J}$ 1969 ;iv: $727-8$.

" Kirchner KA, Smith RM, Gockerman JP, Luke JP. Hereditary thrombotic thrombocytopenic purpura: microangiopathic hemolytic anemia, thrombocytopenia and renal insufficiency occurring in consecutive generations. Nephron 1982:30:28-30

Wallace DC. Lovric A. Clubb JS, Carseldine DB. Thrombotic thrombocytopenic purpura in four siblings. Am J Med 1975:58:724-34.

" Fuchs WE. George JN. Dotin LN, Scars DA. Thrombotic thrombocytopenic purpura occurrence two years apart during late pregnancy in two sisters. JAMA 1976:235:2126-7.

"Remuzzi G. Rossi EC. Misiani R. et al. Prostacyclin and thrombotic microangiopathy. Semin Thromb Hemost 1980;6: $391-8$.

"Hellman RM, Jackson DV, Buss DH. Thrombotic thrombocytopenic purpura and hemolytic uremic syndrome in HLA identified siblings. Ann Intern Med 1980):93:283-4.

Correspondence to Dr J Horowitz, Department of Pediatrics A Central Emek Hospital, Afula, Israel.

Accepted 7 January 1988 